\title{
GCU
}

Glasgow Caledonian

University

University for the Common Good

\section{Is it currently possible to evaluate the risk posed by PERVs for clinical xenotransplantation?}

Denner, Joachim; Scobie, Linda; Schuurman, Henk-Jan

Published in:

Xenotransplantation

DOI:

10.1111/xen.12403

Publication date:

2018

Document Version

Author accepted manuscript

Link to publication in ResearchOnline

Citation for published version (Harvard):

Denner, J, Scobie, L \& Schuurman, H-J 2018, 'Is it currently possible to evaluate the risk posed by PERVs for clinical xenotransplantation?', Xenotransplantation, vol. 25, no. 4, e12403, pp. e12403.

https://doi.org/10.1111/xen.12403

\section{General rights}

Copyright and moral rights for the publications made accessible in the public portal are retained by the authors and/or other copyright owners and it is a condition of accessing publications that users recognise and abide by the legal requirements associated with these rights.

Take down policy

If you believe that this document breaches copyright please view our takedown policy at https://edshare.gcu.ac.uk/id/eprint/5179 for details of how to contact us. 
1

2

COMMENTARY

3

4 Is it currently possible to evaluate the risk posed by PERVs for

5 clinical xenotransplantation?

6

7 Joachim Denner ${ }^{1}$, Linda Scobie ${ }^{2}$, Henk-Jan Schuurman ${ }^{3}$

$8 \quad{ }^{1}$ Robert Koch Institute, Berlin, Germany

$9 \quad{ }^{2}$ School of Health and Life Sciences, Glasgow Caledonian University, Glasgow, G4 0BA, UK

$10{ }^{3}$ SchuBiomed Consultancy, Utrecht, The Netherlands

11

12

Correspondence

13 Joachim Denner, Robert Koch Institute, Berlin, Germany (E-mail address: DennerJ@rki.de)

14

15

Keywords

16

Porcine endogenous retroviruses, virus safety, solid organ xenotransplantation, islet cell

17 xenotransplantation 
The risk of transmission of porcine microorganisms is, in addition to the immunological rejection and the physiological incompatibilities, a major hurdle to the clinical use of pig cells, tissues and organs for the treatment of organ failure in humans, to overcome the medical need caused by the increasing lack of human donors. Whereas most of the porcine microorganisms may be eliminated by early weaning, colostrum deviation, vaccination, antiviral drugs, animal isolation, Caesarean delivery of newborns, and embryo transfer, porcine endogenous retroviruses (PERVs) cannot be eliminated this way because they are integrated in the genome of all pigs [1]. Only a few years before evidence was published that PERV is able to infect human cells [2], two other retroviruses, simian immunodeficiency virus of chimpanzees (SIVcpz) and simian immunodeficiency virus from sooty mangabeys (SIVsm), now called human immunodeficiency viruses 1 and 2 (HIV-1 and 2), invaded the human population causing the fatal acquired immunodeficiency syndrome (AIDS) [3, 4]. Although HIV and PERVs are not very closely related, the fact that PERV is a retrovirus makes it so difficult to evaluate its risk [5]. Also, although most retroviruses are immunosuppressive in the infected host, the absence of an animal model makes it difficult to show this for PERV [6].

In recent years several strategies have been exploited to evaluate the risk posed by PERV, such as (i) infection experiments in vitro, (ii) infection experiments in vivo in small laboratory animals and in nonhuman primates (NHPs) with and without immunosuppression, (iii) preclinical trials in NHPs transplanting pig cells and organs with and without immunosuppression, and (iv) clinical trials mostly using encapsulated pig islet cells without immunosuppression. Despite these substantial efforts, these studies do not allow to make unequivocal conclusions whether PERVs pose a risk in the case of treatment of humans with porcine cells, tissues or solid organs, as will be discussed in the sections below. Unfortunately, there are no alternative approaches to test this in an experimental setting: essentially clinical trials are needed to answer this question. 
There are three types of PERV, PERV-A and PERV-B which are present in the genome of all cells and which infect human cells (human-tropic viruses), and PERV-C which is present in most, but not all pigs and infects only pig cells (ecotropic virus) (for review see [1]). This means that PERV-A and PERV-B are able to infect different human cells and cell lines in vitro, in cell culture [2]. Recombinant viruses between PERV-A and PERV-C (PERV-A/C), able to infect human cells and characterized by a high replication rate, been have described [1]. Some human cell lines such as the 293 pig embryonic kidney cell line are highly susceptible, and after repeated passages of PERV through these human cells, the virus showed a higher replication rate and genetic changes in its long-terminal repeat (LTR). These viruses were called "human cell-adapted PERVs" [7]. The lack of the restriction factor apolipoprotein B-editing catalytic polypeptide-like subunit (APOBEC) and transformation by DNA viruses are thought to be the reason for the high susceptibility of 293 cells. However, primary cells including porcine aortic endothelial cells (PAEC) and peripheral blood mononuclear cells (PBMCs) have also been infected [8, 9]. PBMCs can more effectively be infected with human cell-adapted PERVs, however it remains unclear whether the virus infection is productive, e.g., whether the virus infects cells and produces excess progeny [10]. In the case of PAEC, a productive infection including mRNA production and particle release have been demonstrated [8]. Güell et al. [11] described the infection of human umbilical vein endothelial cells (HUVECs) with PERV, and the presence of proviral DNA in the infected cells. However it was not clear how the HUVECs had been derived and whether the infection was productive. Furthermore, all infection experiments, including the experiment with HUVECs, have been performed using PK15 cells or heavily infected 293 cells as virus source, both releasing high amounts of virus. In contrast, most primary pig cells, for example pig PBMCs, show only a low PERV expression at the RNA level and no virus release [12]. Only after mitogenic stimulation of some pig PBMCs, virus particles were released that were able to infect human 
293 cells $[12,13]$. Therefore, these in vitro studies have only a limited relevance for the evaluation whether PERVs pose a risk for xenotransplantation (Table 1).

\section{Infection experiments in vivo}

PERV-A and PERV-B infect not only human cells in vitro, but also cells of other species (polytropic viruses), with some exceptions such as mouse cells [1, 14-18]. Based on these results numerous attempts have been undertaken to establish a small laboratory animal model of PERV infection (Table 1). However, injection of PERV preparations into mice, rats, guinea pigs, and minks, with or without immunosuppression, failed to infect these animals [15-19]. Cells from NHPs could also be infected in vitro, however in most cases this did not result in a productive infection $[17,19]$. In some cases, e.g., chimpanzee cells, only human cell-adapted PERVs were able to show infection [20]. When three NHP species, namely baboons, rhesus monkeys and pig-tailed monkeys, were inoculated with human cell-adapted PERV-A/C, and the animals were treated daily with three different immunosuppressive drugs (cyclosporine, everolimus (RAD), and methylprednisolone), no PERV infection was observed during a follow-up of more than 300 days [17, 21].

Inoculation of rats with PERV or PERV-producing cells [22], or pig islet cells [16], as well as treatment of minks [18] or guinea pigs [22] with PERV did not result in infection. Only in guinea pigs a transient infection was observed [23]. Mice could not be infected [15, 24], because mice lack a PERV receptor [25]. Noteworthy, early reports on PERV infection of SCID mice [26, 27] and athymic mice [28] proved to represent an artifact based on pseudotyping with endogenous murine retroviruses [29, 30]. Mice transgenic for the human PERV receptor huPAR-2 have been generated, and it was reported that they could be infected 
with PERV in vivo [31]. Although this is the only known in vivo model of PERV infection, no follow-up studies on pathogenic effects of the virus were published.

In rhesus and cynomolgus macaques, and baboons, the main virus receptor PAR-1 was found to be genetically deficient by a mutation at the same position as reported in mice, which is one explanation for the inefficient infection [32]. The receptor in African green monkeys does not have this mutation, but nevertheless the replication is quite low [32].

To summarize, all small laboratory animal and NHP model systems are not suitable to evaluate the risk posed by PERVs or to study PERV pathogenesis (Table 1).

\section{Preclinical trials in NHPs}

In recent years a number of pig-to-NHP preclinical xenotransplantation studies have been performed regarding hearts, kidneys, islet cells, or studies performing perfusion of pig liver, under immunosuppression (for review see [1]). In all these studies, and also in more recent transplantations not listed in [1], i.e., studies on islet cell transplantation in marmosets [33] and cynomolgus monkeys [34], no PERV transmission was observed. However, since the PERV receptor in NHPs is not functional, these results cannot be used to evaluate the safety of xenotransplantation using pig cells and organs (Table 1). Hence, it does not make sense to include the monitoring for PERV transmission in pivotal nonclinical trials before phase transition to clinical development. Interestingly, some regulatory agencies require such studies, which are elaborate and time consuming, and essentially not informative. 
In the past, more than 200 humans have received a xenotransplantation product comprising pig cells or tissues including ex vivo perfusion of pig organs or pig-cell based bioreactors ([35, 36], reviewed in [1] and [37]. No evidence for virus transmission was obtained using sensitive PCR-based methods and immunological assays for the detection of antiviral antibodies. Neither antibodies against PERV as an indirect sign of infection, nor provirus integration in PBMCs of the patients was observed.

During the last years further clinical trials have been performed, including the first prospective clinical trials under proper regulatory oversight using encapsulated pig islet cells to treat type one-diabetes in New Zealand [38] and Argentina [39]. Although the clinical efficacy in these trials was limited, no PERV transmission has been observed [40, 41].

In all of these porcine islet clinical trials no immunosuppression was given and the islet cells were transplanted encapsulated in biopolymers, a procedure which protects from host's humoral and cellular immune system (immunoglobulins and immune cells), but also which prevents release of PERVs (Table 1). After some pioneering explorations more than 40 years ago, transplantation of a large vascularized organ accompanied by an effective pharmaceutical immunosuppression has still not been performed.

\section{Perspectives}

Although human cells can be infected with PERVs under specific and somewhat artificial conditions, i.e., co-culture of human cells with porcine cell lines that do not resemble primary pig cells regarding PERV expression and virus production, or co-culture of porcine cells which human target cell lines that do not resemble primary human cells, no PERV 
particles or PERV-producing cells into small laboratory animals or NHPs, no PERV transmission has been observed. In addition, no PERV transmission was observed in preclinical trials transplanting encapsulated pig islets in diabetic NHPs or transplanting kidneys or hearts into immunosuppressed NHPs. Noteworthy, the trials and infection experiments in NHPs are limited by the lack of a functional PERV receptor in NHPs. Trials in

147 humans used mainly encapsulated pig islet cells. Encapsulation prevents immune rejection, but could also prevent the release of PERV and other pathogens. Ex vivo perfusion of pig liver and spleen by human blood, pig skin transplantations, and injection of pig neuronal cells into the immunoprotected human brain, have also been performed [35, 36]; but till now transplantations of vascularized pig organs under chronic immunosuppression have not been

152 performed. At present there are no additional experimental approaches available to evaluate 153 whether PERVs pose a risk.

During the last years, first reports have been published that PERVs in the genome can be inactivated by CRISPR/Cas9-mediated gene editing tools [42], and also that this procedure allows the generation of live pigs with all PERVs being inactivated [43]. Although the functionality has been shown in in vitro cell culture, with inherent low translation value to the pig-to-human clinical situation as outlined above, it needs to be shown in an in vivo situation that the inactivation of PERVs in the pig donor makes sense, also in relation to the off-target effects of the gene editing procedure [44].

This aside, the possibility of gene editing resulting in inactivated PERVs raised the question 162 whether conventional pigs can still be used for xenotransplantation, or whether only 163 CRISPR/Cas9-inactivated pigs have to be used as source animals for future xenotransplantations [11, 44-46]. PERV proviruses inactivated by CRISPR/Cas9 cannot be restored by recombination, since in all proviruses the gene coding for the important reverse 


\section{CONFLICT OF INTEREST}

$\mathrm{H}-\mathrm{J} \mathrm{S}$ is director at SchuBiomed Consultancy, and provides consultancy in the biomedical sector worldwide. JD and LS have no conflicts of interest.

ORCID

Joachim Denner http://orcid.org/0000-0003-3244-6085

Henk-Jan Schuurman http://orcid.org/0000-0002-3277-7741 


\section{REFERENCES}

1. DenNeR J, TÖNJes RR. Infection barriers to successful xenotransplantation focusing on porcine endogenous retroviruses. Clin Microbiol Rev. 2012; 25(2):318-343.

2. Patience C, TAKeUChi Y, Weiss RA. Infection of human cells by an endogenous retrovirus of pigs. Nat Med. 1997;3(3):282-286.

3. Gao F, Bailes E, Robertson DL, Chen Y, Rodenburg CM, Michael SF, Cummins LB, Arthur LO, Peeters M, Shaw GM, Hahn BH. Origin of HIV-1 in the chimpanzee Pan troglodytes troglodytes. Nature. 1999;397:436-441.

4. Gao F, Yue L, Robertson DL, Hill SC, Hui H, Bigga, RJ, Neequaye Ae, Whelan TM, Ho DD, SHAW GM, HAHN BH. Genetic diversity of human immunodeficiency virus type 2: evidence for distinct sequence subtypes with differences in virus biology. $J$. Virol. 1994;68:7433-7447.

5. VAN DER PoOL HY. Xenotransplantation: progress and promise. West J. Med. 1999;171:333-335.

6. TACKe SJ, Kurth R, Denner J. Porcine endogenous retroviruses inhibit human immune cell function: risk for xenotransplantation? Virology. 2000;268(1):87-93.

7. Denner J, Specke V, Thiesen U, Karlas A, Kurth R. Genetic alterations of the long terminal repeat of an ecotropic porcine endogenous retrovirus during passage in human cells. Virology. 2003;314(1):125-133.

8. Martin U, Winkler ME, Id M, Radeke H, Arseniev L, Takeuchi Y, Simon AR, Patience C, Haverich A, Steinhoff G. Productive infection of primary human endothelial cells by pig endogenous retrovirus (PERV). Xenotransplantation. 2000;7(2):138-142.

9. SPECKE V, RubANT S, DenNer J. Productive infection of human primary cells and cell lines with porcine endogenous retroviruses. Virology. 2001;285(2):177-180.

10. DenNeR J. Porcine endogenous retrovirus infection of human peripheral blood mononuclear cells. Xenotransplantation. 2015;22(2):151-152.

11. GÜEll M, Niu D, Kan Y, George H, Wang T, Lee I-H, Wang G, Church G, Yang L. PERV inactivation is necessary to guarantee absence of pig-to-patient PERVs transmission in xenotransplantation, Xenotransplantation. 2017; 24(6), doi: 10.1111/xen.1

12. Dieckhoff B, Kessler B, Jobst D, Kues W, Petersen B, Pfeifer A, Kurth R, Niemann H, Wolf E, Denner J. Distribution and expression of porcine endogenous retroviruses in multi-transgenic pigs generated for xenotransplantation. Xenotransplantation. 2009;16(2):64-73.

13. Wilson CA, Wong S, Muller J, Davidson CE, Rose TM, Burd P. Type C retrovirus released from porcine primary peripheral blood mononuclear cells infects human cells. J Virol. 1998;72(4):3082-3087.

14. Takeuchi Y, Patience C, Magre S, Weiss RA, Banerjee PT, Le Tissier P, Stoye JP. Host range and interference studies of three classes of pig endogenous retrovirus. $\mathrm{J}$ Virol. 1998;72(12):9986-9991.

15. Irgang M, Karlas A, Laue C, Specke V, Tacke SJ, Kurth R, Schrezenmeir J, DENneR J. Porcine endogenous retroviruses PERV-A and PERV-B infect neither mouse cells in vitro nor SCID mice in vivo. Intervirology. 2005;48(2-3):167-173. 
16. Denner J, Specke V, Karlas A, Chodnevskaja I, Meyer T, Moskalenko V, KURTH R, UlRICHS K. No transmission of porcine endogenous retroviruses (PERVs) in a long-term pig to rat xenotransplantation model and no infection of immunosuppressed rats. Ann Transplant. 2008;13(1):20-31.

17. Specke V, Schuurman HJ, Plesker R, Coulibaly C, Ozel M, Langford G, Kurth R, DENNER J. Virus safety in xenotransplantation: first exploratory in vivo studies in small laboratory animals and non-human primates. Transpl Immunol. 2002;9(24):281-288.

18. Specke V, Plesker R, Coulibaly C, Boller K, Denner J. Productive infection of a mink cell line with porcine endogenous retroviruses (PERVs) but lack of transmission to minks in vivo. Arch Virol. 2002;147(2):305-319.

19. Ritzhaupt A, Van Der LaAn LJ, Salomon DR, Wilson CA. Porcine endogenous retrovirus infects but does not replicate in nonhuman primate primary cells and cell lines. J Virol. 2002;76(22):11312-11320.

20. Karlas A, Irgang M, Votteler J, Specke V, Ozel M, Kurth R, Denner J. Characterisation of a human cell-adapted porcine endogenous retrovirus PERV-A/C. Ann Transplant. 2010;15(2):45-54.

21. Specke V, R. Plesker, J. Wood, C. Coulibaly, K. Suling, et al. No in vivo infection of triple immunosuppressed non-human primates after inoculation with high titers of porcine endogenous retroviruses. Xenotransplantation. 2009;16:34-44.

22. Specke V, Tacke S, Boller K, Schwendemann J, Denner J. Porcine endogenous retroviruses (PERVs): In vitro host range and attempts to establish small animal models. J Gen Virol. 2001;82:837-844.

23. Argaw T, Colon-Moran W, Wilson CA. Limited infection without evidence of replication by porcine endogenous retrovirus in guinea pigs. J Gen Virol. 2004;85(Pt 1):15-19.

24. Kuddus R. H., D. M. Metes, M. A. NalesniK, A. J. Logar, A. S. RaO, et Al. Porcine cell microchimerism but lack of productive porcine endogenous retrovirus (PERV) infection in naive and humanized SCID-beige mice treated with porcine peripheral blood mononuclear cells. Transpl Immunol. 2004;13:15-24.

25. Ericsson, T. A., Y. Takeuchi, C. Templin, G. Quinn, S. F. Farhadian, et al. Identification of receptors for pig endogenous retrovirus. Proc Natl Acad Sci USA. 2003;100:6759-6764.

26. Deng YM, TuCH BE, RAWLinson WD. Transmission of porcine endogenous retroviruses in severe combined immunodeficient mice xenotransplanted with fetal porcine pancreatic cells. Transplantation. 2000;70:1010-1016.

27. VAn Der LaAn, L. J., C. LOCKey, B. C. Griffeth, F. S. Frasier, C. A. Wilson, et AL. Infection by porcine endogenous retrovirus after islet xenotransplantation in SCID mice. Nature. 2000;407:90-94.

28. Clémenceau B, JÉgou D, Martignat L, SaÏ P. Microchimerism and transmission of porcine endogenous retrovirus from a pig cell line or specific pathogen-free pig islets to mouse tissues and human cells during xenografts in nude mice. Diabetologia. 2002;45:914-923. 
29. Martina, Y., S. Kurian, S. Cherqui, G. Evanoff, C. Wilson, et Al. Pseudotyping of porcine endogenous retrovirus by xenotropic murine leukemia virus in a pig islet xenotransplantation model. Am J Transplant. 2005;5:1837-1847.

30. YANG YG, WoOd JC, LAN P, WiLKinson RA, SyKes M, ET AL. Mouse retrovirus mediates porcine endogenous retrovirus transmission into human cells in long-term human-porcine chimeric mice. J Clin Invest. 2004;114:695-700.

31. Martina Y, Marcucci KT, Cherqui S, Szabo A, Drysdale T, et Al. Mice transgenic for a human porcine endogenous retrovirus receptor are susceptible to productive viral infection. J Virol. 2006;80:3135-3146. Erratum in: J. Virol. 80:5100.

32. Mattiuzzo G, TAKeuchi Y. Suboptimal porcine endogenous retrovirus infection in non-human primate cells: implication for preclinical xenotransplantation. PLoS One. 2010;5(10):e13203.

33. Plotzki e, Wolf-van Buerck L, Knauf Y, Becker T, Maetz-Rensing K, Schuster M, Baehr A, Klymiuk N, Wolf E, Seissler J, Denner J. Virus safety of islet cell transplantation from transgenic pigs to marmosets. Virus Res. 2015;204:95102.

34. Morozov VA, Ludwig S, Ludwig B, Rotem A, Barkai U, Bornstein SR, Denner J. Islet cell transplantation from Göttingen minipigs to cynomolgus monkeys: analysis of virus safety. Xenotransplantation. 2016;23(4):320-7.

35. Paradis K, Langford G, Long Z, Heneine W, SAndstrom P, Switzer WM, CHAPMAN LE, LOCKEY C, ONIONS D, OTTO E. Search for cross-species transmission of porcine endogenous retrovirus in patients treated with living pig tissue. The XEN 111 Study Group. Science. 1999;285(5431):1236-1241.

36. Scobie L1, Padler-Karavani V, Le Bas-Bernardet S, Crossan C, Blaha J, Matouskova M, Hector RD, Cozzi E, Vanhove B, Charreau B, Blancho G, Bourdais L, Tallacchini M, Ribes JM, Yu H, Chen X, Kracikova J, Broz L, Hejnar J, Vesely P, TAKeUChi Y, VARKi A, Soulillou JP. Long-term IgG response to porcine Neu5Gc antigens without transmission of PERV in burn patients treated with porcine skin xenografts. J Immunol. 2013;191(6):2907-2915.

37. Denner, J., H. SchuUrman, And C. Patience. The International Xenotransplantation Association consensus statement on conditions for undertaking clinical trials of porcine islet products in type 1 diabetes - Chapter 5: Strategies to prevent transmission of porcine endogenous retroviruses. Xenotransplantation. 2009;16:239 248.

38. Matsumoto S, Abalovich A, Wechsler C, Wynyard S, Elliott RB. Clinical Benefit of Islet Xenotransplantation for the Treatment of Type 1 Diabetes. EBioMedicine. 2016;12:255-262.

39. Cooper DK, Matsumoto S, Abalovich A, Itoh T, Mourad NI, Gianello PR, Wolf E, Cozzi E. Progress in Clinical Encapsulated Islet Xenotransplantation. Transplantation. 2016;100(11):2301-2308.

40. Wynyard S, Nathu D, Garkavenko O, Denner J, Elliott R. Microbiological safety of the first clinical pig islet xenotransplantation trial in New Zealand. Xenotransplantation. 2014;21(4):309-23. 
41. Morozov VA, Wynyard S, Matsumoto S, Abalovich A, Denner J, Elliott R. No PERV transmission during a clinical trial of pig islet cell transplantation. Virus Res. 2017;227:34-40.

42. Yang L, Güell M, Niu D, George H, Lesha E, Grishin D, Aach J, Shrock E, Xu W, Poci J, Cortazio R, Wilkinson RA, Fishman JA, Church G. Genome-wide inactivation of porcine endogenous retroviruses (PERVs). Science. 2015;350(6264):1101-1104.

43. Niu D, Wei HJ, Lin L, George H, Wang T, Lee IH, Zhao HY, Wang Y, Kan Y, Shrock E, Lesha E, WANG G, Luo Y, Qing Y, JiaO D, Zhao H, Zhou X, Wang S, WeI H, GÜELL M, CHURCH GM, YANG L. Inactivation of porcine endogenous retrovirus in pigs using CRISPR-Cas9. Science. 2017;357(6357):1303-1307.

44. SCOBIE L, DENNER J, SCHUURMAN HJ. Inactivation of porcine endogenous retrovirus in pigs using CRISPR-Cas9, editorial commentary. Xenotransplantation. 2017; doi: 10.1111/xen.

45. DENNER J. Advances in organ transplant from pigs. Science. 2017;357(6357):12381239.

46. Denner J. Paving the Path toward Porcine Organs for Transplantation. $N$ Engl J Med. 2017;377(19):1891-1893.

47. Suling K, Quinn G, WoOd J, PATIEnCE C. Packaging of human endogenous retrovirus sequences is undetectable in porcine endogenous retrovirus particles produced from human cells. Virology. 2003;312(2):330-336.

48. Cozzi E, TönJes RR, Gianello P, BÜHLER LH, RAYAT GR, MATSUMOTO S, PARK CG, KWON I, Wang W, O'Connell P, Jessamine S, Elliott RB, Kobayashi T, Hering BJ. First update of the International Xenotransplantation Association consensus statement on conditions for undertaking clinical trials of porcine islet products in type 1 diabetes--Chapter 1: update on national regulatory frameworks pertinent to clinical islet xenotransplantation. Xenotransplantation. 2016;23(1):14-24.

49. Kaulitz D, Fiebig U, Eschricht M, Wurzbacher C, Kurth R, Denner J. Generation of neutralising antibodies against porcine endogenous retroviruses (PERVs). Virology. 2011;411(1):78-86.

50. Denner J, Minica D, Kaulitz D, SChmidt CM. Increased titers of neutralizing antibodies after immunization with both envelope proteins of the porcine endogenous retroviruses (PERVs). Virol. J. 2012;9:260.

51. WAechter A, Eschricht M, DenNer J. Neutralization of porcine endogenous retrovirus by antibodies against the membrane-proximal external region of the transmembrane envelope protein. J. Gen. Virol. 2013;94(Pt 3):643-51.

52. WAechter A, Denner J. Novel neutralising antibodies targeting the N-terminal helical region of the transmembrane envelope protein $\mathrm{p} 15 \mathrm{E}$ of the porcine endogenous retrovirus (PERV). Immunol Res. 2014;58(1):9-19.

53. Denner J. Can Antiretroviral Drugs Be Used to Treat Porcine Endogenous Retrovirus (PERV) Infection after Xenotransplantation? Viruses. 2017;9(8). pii: E213. 
Table 1 Evaluation of the results of different PERV transmission experiments

\begin{tabular}{|c|c|c|c|c|}
\hline Setting, method & $\begin{array}{l}\text { Outcome PERV } \\
\text { transmission }\end{array}$ & $\begin{array}{l}\text { Possible reason } \\
\text { why negative }\end{array}$ & $\begin{array}{l}\text { Possible reason } \\
\text { why positive }\end{array}$ & $\begin{array}{l}\text { Outlook, } \\
\text { conclusion }\end{array}$ \\
\hline $\begin{array}{l}\text { Clinical } \\
\text { transplantation of } \\
\text { pig islet and other } \\
\text { cells to humans, ex } \\
\text { vivo perfusion }\end{array}$ & $\begin{array}{l}\text { No } \\
\text { transmission* }\end{array}$ & $\begin{array}{l}\text { Encapsulated cells, } \\
\text { low number, no } \\
\text { immunosuppression }\end{array}$ & & $\begin{array}{l}\text { No relevance for } \\
\text { solid organ } \\
\text { transplantation } \\
\text { into humans }\end{array}$ \\
\hline $\begin{array}{l}\text { Preclinical } \\
\text { transplantation of } \\
\text { different pig organs } \\
\text { into non-human } \\
\text { primates }\end{array}$ & No transmission & $\begin{array}{l}\text { Absence of } \\
\text { functional PERV } \\
\text { receptor }\end{array}$ & & $\begin{array}{l}\text { No relevance for } \\
\text { solid organ } \\
\text { transplantation } \\
\text { into humans }\end{array}$ \\
\hline $\begin{array}{l}\text { Infection } \\
\text { experiments in vivo } \\
\text { in small animals and } \\
\text { non-human } \\
\text { primates (NHP) with } \\
\text { and without } \\
\text { pharmaceutical } \\
\text { immunosuppression }\end{array}$ & $\begin{array}{l}\text { No } \\
\text { transmission** }\end{array}$ & $\begin{array}{l}\text { Absence of PERV } \\
\text { receptor, or } \\
\text { absence of } \\
\text { functional PERV } \\
\text { receptor, or low } \\
\text { PERV receptor } \\
\text { density }\end{array}$ & & $\begin{array}{l}\text { No relevance for } \\
\text { solid organ } \\
\text { transplantation } \\
\text { into humans }\end{array}$ \\
\hline $\begin{array}{l}\text { Infection } \\
\text { experiments in vitro }\end{array}$ & $\begin{array}{l}\text { Infection of } \\
\text { human cells and } \\
\text { cells from other } \\
\text { species }\end{array}$ & & $\begin{array}{l}\text { Use of high } \\
\text { virus load for } \\
\text { infection, target } \\
\text { cells susceptible } \\
\text { due to lack of } \\
\text { restriction } \\
\text { factors, use of } \\
\text { human cell } \\
\text { adapted virus }\end{array}$ & $\begin{array}{l}\text { Only limited } \\
\text { relevance for } \\
\text { transplantation } \\
\text { into humans, } \\
\text { innate and } \\
\text { adaptive immune } \\
\text { system not } \\
\text { present }\end{array}$ \\
\hline
\end{tabular}

* In some patients microchimerism was detected, e.g., the presence of pig cells, but no infection [35].

**Reports showing that SCID mice were infected with PERV [26-28] were the result of an artefact based on pseudotyping between PERV and endogenous murine retroviruses $[29,30]$. 